\title{
An epidemiologically valuable typing method for Neisseria meningitidis by analysis of restriction fragment length polymorphisms
}

\author{
A. J. FOX, D. M. JONES, S. J. GRAY, D. A. CAUGANT* and N. A. SAUNDERSt \\ Manchester Public Health Laboratory, Withington Hospital, Manchester M20 8LR, `National Institute of Public Health, \\ Oslo, Norway and +Central Public Health Laboratory, 61 Colindale Avenue, London NW9 5 HT
}

\begin{abstract}
Summary. A restriction fragment length polymorphism (RFLP) typing method was developed for Neisseria meningitidis. A cloned EcoRI fragment from a Neisseria meningitidis Group B serotype 15P1.16 sulphonamide-resistant strain was used to probe Southern blots of total chromosomal DNA restriction fragments (enzyme AvaI). A group of 75 apparently unrelated organisms gave rise to 26 different restriction fragment length patterns and two different groups of epidemiologically related strains had RFLP patterns that were distinct for each group. The technique was highly reproducible and discriminatory. The RFLP data were compared with the results of serotyping and subtyping and isoenzyme electrophoretotyping. The RFLP data were consistent with those from the alternative typing methods; clones defined by isoenzyme analysis were subdivided by this technique. The use of RFLP typing by cloned probes should be of considerable epidemiological value.
\end{abstract}

\section{Introduction}

Currently, meningococci are typed and subtyped by identifying epitopes on the major outer-membrane proteins with monoclonal antibodies (MAbs). ${ }^{1}$ Determination of the phenotypes in this way has been invaluable in understanding the epidemiology of meningococcal disease. ${ }^{2}$ The disadvantages of phenotyping are occasional poor expression or masking of surface antigens, the constant need to enlarge the reagent panel for "newer" serotypes, and the very limited information given by the method regarding the genetic relatedness of different strains. The use of multilocus enzyme electrophoretotyping has shown that meningococci associated with disease have a clonal organisation. Epidemics of Group A meningococcal disease are usually due predominantly to strains of one clone ${ }^{3}$ and the prevalent endemic Group B strains in many parts of the world may be a clonally related group of strains. ${ }^{4}$ Group B strains defined as the same clone by isoenzyme analysis may have different phenotypes ${ }^{4}$ and strains with similar phenotypes may belong to different clones. Therefore, for a proper appreciation of the epidemiology of meningococcal disease both phenotypic and genomic characters should be determined. As isoenzyme electrophoresis is not a suitable technique for day-today application we have evaluated another typing technique that may also provide data on genetic relationships.

Received 3 July 1990; revised version accepted 5 Sep. 1990.
New molecular techniques such as restriction fragment length polymorphism (RFLP) analysis have been shown to be of value in typing micro-organisms, e.g., legionellae, ${ }^{5}$ staphylococci ${ }^{6}$ and Escherichia coli. ${ }^{7}$ The use of DNA probes to detect restriction fragment length polymorphisms by definition provides a genetic fingerprint of a particular strain.

This report describes the application of cloned meningococcal DNA as a probe for detection of RFLP in Neisseria meningitidis and a preliminary evaluation of the epidemiological value of this technique.

\section{Materials and methods}

\section{Meningococcal strains}

A collection of random isolates (table I) was provided by Dr R. Fallon, Meningococcal Reference Laboratory, Scotland. The strains had been serogrouped, serotyped with MAbs in a whole-cell ELISA, and isoenzyme electrophoretotyped (D.A.C). Two groups of epidemiologically related organisms (table III) were also examined: one group consisted of five isolates from cases of meningococcal disease associated with the Gloucester outbreak (B15P1.16 sulphonamide-resistant meningococci) and nine isolates from carriers related to this outbreak, and the second group of five further B15P1.16 sulphonamideresistant isolates, four of which were associated with a contemporary outbreak of meningococcal disease in Plymouth. Representative strains from these out- 
Table I. Phenotypic and genotypic characteristics of 75 meningococcal isolates

\begin{tabular}{|c|c|c|c|c|}
\hline Isolate no. & Phenotype & $\begin{array}{l}\text { Clinical } \\
\text { source* }\end{array}$ & ET type & $\underset{\text { type }}{\text { RFLP }}$ \\
\hline 1 & BNTR & BC & 1 & 1 \\
\hline 2 & B4/15R & NK & 1 & 1 \\
\hline 3 & B4/15R & NK & 1 & 1 \\
\hline 4 & B4/15R & NK & 1 & 1 \\
\hline 5 & B4/15R & NK & 1 & 1 \\
\hline 6 & B4/15R & NK & 1 & 1 \\
\hline 7 & $\mathrm{NG} 4 / 15 \mathrm{R}$ & TS & 1 & 1 \\
\hline 8 & NG4/15R & TS & 1 & 1 \\
\hline 9 & NG4/15R & TS & 1 & 1 \\
\hline 10 & B4/15R & NK & 1 & 1 \\
\hline 11 & B15/16R & $\mathrm{BC}$ & 1 & 1 \\
\hline 12 & B15/16R & CSF & 1 & 1 \\
\hline 13 & B14/15 & CSF & 2 & 2 \\
\hline 14 & NGS & TS & 3 & 3 \\
\hline 15 & NGS & TS & 4 & 4 \\
\hline 16 & NGS & TS & 5 & 5 \\
\hline 17 & NGS & $\mathbf{M}$ & 6 & 5 \\
\hline 18 & NGS & TS & 7 & 6 \\
\hline 19 & B1S & CSF & 8 & 7 \\
\hline 20 & NGS & SPU & 9 & 8 \\
\hline 21 & NG4/15S & NK & 10 & 6 \\
\hline 22 & $\mathrm{ZNT} / 15 \mathrm{~S}$ & SPU & 11 & 3 \\
\hline 23 & CNTS & BC & 12 & 6 \\
\hline 24 & CNTS & CSF & 12 & 6 \\
\hline 25 & $\mathrm{C} 2 \mathrm{bS}$ & CSF & 12 & 9 \\
\hline 26 & B2aS & CSF & 13 & 2 \\
\hline 27 & NGS & SPU & 14 & 1 \\
\hline 28 & NGS & TS & 14 & 1 \\
\hline 29 & NGS & SPU & 14 & 1 \\
\hline 30 & A4/15S & NK & 14 & 1 \\
\hline 31 & B4/15S & NK & 14 & 10 \\
\hline 32 & BNTS & $\mathrm{BC}$ & 15 & 1 \\
\hline 33 & $\mathrm{BNT} / 15 \mathrm{~S}$ & TS & 16 & 11 \\
\hline 34 & $\mathrm{BNT} / 15 \mathrm{~S}$ & TS & 16 & 11 \\
\hline 35 & $\mathrm{BNT} / 15 \mathrm{~S}$ & TS & 17 & 11 \\
\hline 36 & $\mathrm{BNT} / 15 \mathrm{~S}$ & CSF & 18 & 11 \\
\hline 37 & B4/15S & NK & 19 & 7 \\
\hline 38 & CNT/7,15 & CSF & 20 & 12 \\
\hline 39 & NGS & TS & 21 & 13 \\
\hline 40 & YNT/2,9 & TS & 22 & 14 \\
\hline 41 & B2bS & CSF & 23 & 15 \\
\hline 42 & $\mathrm{~B} 2 \mathrm{bS}$ & $\mathrm{BC}$ & 23 & 16 \\
\hline 43 & B2bS & $\mathrm{BC}$ & 23 & 16 \\
\hline 44 & $\mathrm{~B} 2 \mathrm{bS}$ & CSF & 23 & 16 \\
\hline 45 & $\mathrm{C} 2 \mathrm{bS}$ & CSF & 23 & 17 \\
\hline 46 & $\mathrm{Y} 14 / 2,9 \mathrm{~S}$ & TS & 24 & 12 \\
\hline 47 & $\mathrm{Y} 14 / 2,9 \mathrm{~S}$ & TS & 24 & 12 \\
\hline 48 & $\mathrm{C} 2 \mathrm{~b} / 2,9 \mathrm{~S}$ & TS & 25 & 17 \\
\hline 49 & $\mathrm{C} 2 \mathrm{~b} / 2,9 \mathrm{~S}$ & TS & 25 & 17 \\
\hline 50 & B14R & CSF & 26 & 18 \\
\hline 51 & B14S & CSF & 27 & 1 \\
\hline 52 & NGS & SPU & 26 & 12 \\
\hline 53 & NGS & TS & 27 & 19 \\
\hline 54 & B $1 / 15 S$ & $\mathrm{CSF}$ & 28 & 20 \\
\hline 55 & NGS & TS & 29 & 19 \\
\hline 56 & B4S & NK & 30 & 4 \\
\hline 57 & $\mathrm{Z} 4 / 15 \mathrm{~S}$ & NP & 31 & 21 \\
\hline 58 & NGS & NK & 32 & 18 \\
\hline 59 & $\mathrm{C} 2 \mathrm{aR}$ & BC & 33 & 22 \\
\hline 60 & $\mathrm{C} 2 \mathrm{a} / 2,9 \mathrm{R}$ & CSF & 33 & 23 \\
\hline 61 & $\mathrm{C} 2 \mathrm{a} / 2,9 \mathrm{R}$ & $\mathrm{BC}$ & 33 & 23 \\
\hline 62 & $\mathrm{C} 2 \mathrm{aR}$ & CSF & 33 & 22 \\
\hline 63 & $\mathrm{C} 2 \mathrm{aR}$ & CSF & 33 & 8 \\
\hline 64 & C4/9,16R & CSF & 34 & 12 \\
\hline 65 & $\mathrm{C} 4 / 6,2,9 \mathrm{R}$ & CSF & 34 & 24 \\
\hline 66 & $\mathrm{C} 4 / 7,9 \mathrm{R}$ & CSF & 34 & 24 \\
\hline 67 & $\mathrm{C} 4 / 15 \mathrm{~S}$ & $\mathrm{CSF}$ & 34 & 18 \\
\hline 68 & NGS & EYE & 34 & 18 \\
\hline 69 & $\mathrm{C} 4 \mathrm{~S}$ & CSF & 34 & 18 \\
\hline 70 & $\mathrm{C} 2 \mathrm{a} / 2 \mathrm{R}$ & BC & 35 & 8 \\
\hline 71 & $\mathrm{NG} 2 \mathrm{~b} / 2,9 \mathrm{~S}$ & CSF & 36 & 25 \\
\hline 72 & B4S & BC & 37 & 7 \\
\hline 73 & B4S & TS & 37 & 11 \\
\hline
\end{tabular}

\begin{tabular}{c|lllc}
\hline Isolate no. & Phenotype & $\begin{array}{c}\text { Clinical } \\
\text { source* }\end{array}$ & ET type & $\begin{array}{c}\text { RFLP } \\
\text { type }\end{array}$ \\
\hline 74 & BNT/15R & BC & 38 & 11 \\
75 & B2bS & BC & 39 & 26 \\
\hline
\end{tabular}

* Phenotype expressed as Group, type/subtype, sulphonamide sensitive (S) or resistant (R)

BC, blood culture; NK, not known; TS, throat swab; CSF, cerebrospinal fluid; $M$, mouth; SPU, sputum; NP, nasopharyngeal aspirate.

breaks had been isoenzyme electrophoretotyped previously (Dr R. A. Wall, Clinical Research Centre, Watford Road, Harrow).

\section{Preparation of DNA}

Meningococcal DNA was prepared essentially as described for Legionella spp. ${ }^{6}$ After incubation for $18 \mathrm{~h}$ in an atmosphere of air $+\mathrm{CO}_{2} 5 \%$ at $37^{\circ} \mathrm{C}$ on blood agar, bacterial growth was harvested for isolation of chromosomal DNA. Bacterial cells were treated with lysozyme $(100 \mu \mathrm{l}: 2 \mathrm{mg} / \mathrm{ml})$ in sucrose $25 \%, 50 \mathrm{mM}$ Tris $\mathrm{HCl}, \mathrm{pH} 8.0$, for $10 \mathrm{~min}$ at room temperature. Bacterial lysis was accomplished by adding $5 \mathrm{~m}$ guanidine isothiocyanate, $0.1 \mathrm{M}$ EDTA, $\mathrm{pH} 7 \cdot 0(150 \mu \mathrm{l})$. The crude lysate was mixed by gentle pipetting and $150 \mu \mathrm{l}$ of $3 \mathrm{M}$ ammonium acetate was added; the mixture was then emulsified with an equal volume of chloroform: isoamyl alcohol $(24: 1 \mathrm{v}: \mathrm{v})$. The resulting phases were separated by high speed centrifugation in a microfuge and the aqueous phase was removed. The DNA was recovered from the aqueous phase by isopropanol precipitation ( 0.54 volume). The DNA pellet was washed once with ethanol $70 \%$, dried in vacuo and resuspended in $10 \mathrm{mM}$ Tris $\mathrm{HCl}, \mathrm{pH} 7.5$, 1 mM EDTA buffer.

\section{Restriction endonuclease digestion}

Meningococcal DNA samples $(5 \mu \mathrm{g})$ were treated with the restriction enzymes EcoRI, PstI, HindIII, HaeIII and AvaI for $2 \mathrm{~h}$ at $37^{\circ} \mathrm{C}$. The resulting fragments were electrophoresed in agarose (ultrapure agarose; Gibco BRL) $0.8 \%$ gels, stained with ethidium bromide, examined by UV transillumination and then Southern blotted.

\section{RFLP method}

For RFLP analysis, $5 \mu \mathrm{g}$ of chromosomal DNA was digested with the restriction enzyme $A v a \mathrm{I}$ and the fragments were separated by electrophoresis in agarose $0.8 \%$ with 0.045 м Tris-borate, 0.001 M EDTA electrophoresis buffer. The electrophoresed digest was then transferred, following depurination, denaturation and neutralisation, to a nylon membrane (Hybond $\mathrm{N}$ Amersham International plc) in a vacuum-assisted 
transfer device (Vacugene, Pharmacia LKB Ltd). The transferred DNA fragments were cross linked to the nylon membrane by exposure to UV light for $3 \mathrm{~min}$. The membrane was then pre-hybridised for $1 \mathrm{~h}$ at $42^{\circ} \mathrm{C}$ in hybridisation buffer containing formamide $45 \% \mathrm{v} / \mathrm{v}, 5 \times$ SSPE, $5 \times$ Denhardt's solution, and hybridised for $18 \mathrm{~h}$ at $42^{\circ} \mathrm{C}$ after the addition of heat denatured biotinylated DNA probe. The membrane was washed at low stringency. Probe binding fragments were visualised with the Blugene ${ }^{\circledR}$ (Gibco BRL) or digoxigenin (Boehringer Manheim UK) nonradioactive DNA probe detection kit. Size markers consisting of PstI-digested phage DNA were included on the outside tracks of each electrophoretic run.

\section{The probe}

The probe, designated $\lambda \mathrm{MN} 3$, which encodes a random fragment of the meningococcal genome, was randomly selected from a DNA library prepared in the $\lambda$ phage vector $\lambda$ gt WES B. Growth of $\lambda$ phage and purification of phage DNA was as described in Maniatis $e t a l{ }^{8}$ The meningococcal insert was not excised from the purified phage DNA, which enabled probe DNA to bind to PstI fragments of phage DNA and to be run as size standards on each electrophoresis gel. The inclusion of these standards with every run provided control for the various stages of the procedure. The phage DNA containing the probe fragment was labelled with either biotin-11-dUTP (Sigma) by means of a random primed DNA labelling kit (Boehringer Manheim UK) or digoxigenin labelled with a digoxigenin labelling and detection kit (Boehringer Manheim UK).

\section{RFLP evaluation}

Analysis of RFLPs as a method for epidemiological typing of $N$. meningitidis was evaluated by determination of (a) the reproducibility, (b) the intra-strain stability, and (c) the discriminatory index of the technique. Reproducibility was assessed by examining the performance of separate batches of probe prepared in different laboratories, and by using two different non-isotopic labelling techniques. Intra-strain stability was evaluated by comparison of RFLP patterns obtained with a test panel of organisms: (a) for DNA prepared on two separate occasions from the same organisms following recovery from glass beads at $-70^{\circ} \mathrm{C}$; (b) for three isolates cultured on Difco GC medium plus GC supplements (DB), blood agar, Kellog's medium, chocolate agar and a $N$. meningitidis selective medium containing antibiotics; (c) for epidemiologically associated isolates from cases and carriers; (d) for isolates from different clinical sites from the same patient; (e) for meningococci isolated at intervals of 3-6 months from long-term carriers; (f) for DNA prepared on every tenth day from a group of organisms which were serially subcultured 40 times.

\section{Discriminatory index}

The discrimination of the method was determined by examining the number and frequency of different serotypes, isoenzyme electrophoretotypes and RFLP types amongst the 75 unrelated isolates. The numerical index of discrimination was calculated for all three techniques as described by Hunter and Gaston. ${ }^{9}$

\section{Results}

\section{Reproducibility}

Of the restriction enzymes tried, AvaI was chosen because it gave the best discrimination and optimal number of bands. Some strains showed only one band; multiple bands for other meningococcal strains probably indicate the presence of repeated sequences that hybridise with the probe. Faint bands observed with some strains probably reflected binding of the probe to partial sequences or some hybridisation to sequences with more distant homology at the low levels of stringency employed. The characteristic patterns of bands observed for individual strains were independent of time of recovery, the batch of $\lambda \mathrm{MN} 3$ DNA used, and the two methods of non-isotopic labelling of the DNA probe.

\section{Intra-strain stability}

Restriction fragment patterns obtained with three different meningococcal strains were indistinguishable regardless of the culture medium used (table II), which demonstrates that the genotype judged by RFLP typing was independent of nutritional growth conditions. The restriction fragment patterns obtained with three isolates sampled at intervals during 40 cycles of

Table II. Effect of different growth media and serial passage of isolates on RFLP pattern

\begin{tabular}{|c|c|c|c|c|c|}
\hline $\begin{array}{c}\text { Isolate } \\
\text { no. }\end{array}$ & Serotype & $\begin{array}{l}\text { Growth } \\
\text { medium }\end{array}$ & $\begin{array}{c}\text { RFLP } \\
\text { type }\end{array}$ & $\begin{array}{c}\text { Passage } \\
\text { no. }\end{array}$ & $\begin{array}{c}\text { RFLP } \\
\text { type }\end{array}$ \\
\hline 12 & B15/16R & $\begin{array}{l}\text { DB } \\
\text { BA } \\
\text { KE } \\
\text { CH } \\
\text { MN }\end{array}$ & $\begin{array}{l}1 \\
1 \\
1 \\
1 \\
1\end{array}$ & $\begin{array}{l}\text { P1 } \\
\text { P10 } \\
\text { P20 } \\
\text { P30 } \\
\text { P40 }\end{array}$ & $\begin{array}{l}1 \\
1 \\
1 \\
1 \\
1\end{array}$ \\
\hline 41 & B2bS & $\begin{array}{l}\text { DB } \\
\text { BA } \\
\text { KE } \\
\text { CH } \\
\text { MN }\end{array}$ & $\begin{array}{l}15 \\
15 \\
15 \\
15 \\
15\end{array}$ & $\begin{array}{l}\text { P1 } \\
\text { P10 } \\
\text { P20 } \\
\text { P30 } \\
\text { P40 }\end{array}$ & $\begin{array}{l}15 \\
15 \\
15 \\
15 \\
15\end{array}$ \\
\hline 71 & $\mathrm{NG} 2 \mathrm{~b} / 2,9 \mathrm{~S}$ & $\begin{array}{l}\text { DB } \\
\text { BA } \\
\text { KE } \\
\text { CH } \\
\text { MN }\end{array}$ & $\begin{array}{l}25 \\
25 \\
25 \\
25 \\
25\end{array}$ & $\begin{array}{l}\text { P1 } \\
\text { P10 } \\
\text { P20 } \\
\text { P30 } \\
\text { P40 }\end{array}$ & $\begin{array}{l}25 \\
25 \\
25 \\
25 \\
25\end{array}$ \\
\hline
\end{tabular}

DB, Difco GC medium plus GC supplements; BA, blood agar; KE, Kellog's medium; $\mathrm{CH}$, chocolate agar; $\mathrm{MN}$, N. meningitidis selective medium containing antibiotics. 
repeated subculture were identical throughout (table II). Isolates obtained from different sites of the same patient and patient contacts had constant RFLP patterns as did isolates obtained at different times from long-term carriers of meningococci providing additional evidence that the RFLP pattern is stable for a particular strain. The results of the RFLP analysis confirming the intra-strain stability of the isolates described above are summarised in tables II and III.

The RFLP patterns shown in fig. 1 and summarised in table III for five isolates from cases of invasive meningococcal disease (tracks 3-7) were identical with each other and with the patterns of nine carriage isolates obtained from volunteers (fig. 2) as part of an investigation (Stonehouse Meningococcal Survey) ${ }^{10}$ into the Gloucestershire outbreak of B15P1.16 meningococcal infection. Each of the isolates gave indistinguishable patterns (RFLP type 1) providing further confirmation that the isolates from cases and identified carriers were epidemiologically related.

The RFLP patterns (fig. 1a, tracks 9-11) obtained with four isolates from Plymouth were identical with each other but distinct from that obtained with the phenotypically identical organisms involved in the Gloucester outbreak, whereas some isolates from elsewhere in the UK gave patterns identical to the Gloucester strains (fig. 1, track 11).

\section{Discrimination between strains}

Examination of the RFLP patterns obtained with the 75 apparently unrelated meningococcal isolates revealed 26 RFLP types of which seven distinct RFLP

Table III. Results obtained with isolates from cases and carriers associated with two UK outbreaks

\begin{tabular}{l|rlcc}
\hline $\begin{array}{c}\text { Isolate } \\
\text { no. }\end{array}$ & Serotype & $\begin{array}{c}\text { Clinical } \\
\text { source }\end{array}$ & $\begin{array}{c}\text { RFLP } \\
\text { type }\end{array}$ & $\begin{array}{c}\text { Geographical } \\
\text { source }\end{array}$ \\
\hline D639 & B15/16R & CSF & 1 & GLOS \\
F825 & B15/16R & CSF & 1 & GLOS \\
F1187 & B15/16R & CSF & 1 & GLOS \\
G16 & B15/16R & BC & 1 & GLOS \\
G217 & B15/16R & CSF & 1 & GLOS \\
1453 & B15/16R & TS & 1 & SH \\
1483 & B15/16R & TS & 1 & SH \\
1495 & B15/16R & TS & 1 & SH \\
1497 & NG15/16R & TS & 1 & SH \\
1499 & B15/16R & TS & 1 & SH \\
1515 & NG15/16R & TS & 1 & SH \\
1525 & B15/16R & TS & 1 & SH \\
1527 & B15/16R & TS & 1 & SH \\
1537 & NG15/16R & TS & 1 & SH \\
H800 & B15/16R & CSF & 27 & PLY \\
J2015 & B15/16R & BC & 27 & PLY \\
J2309 & B15/16R & CSF & 27 & PLY \\
K41 & B15/16R & CSF & 27 & PLY \\
K52 & B15/16R & CSF & 1 & PONT \\
& & & & \\
\hline
\end{tabular}

CSF, cerebrospinal fluid; BC, blood culture; TS, throat swab; GLOS, Gloucestershire; SH, Stonehouse associated with Gloucestershire outbreak; PLY, Plymouth; PONT, Pontefract.

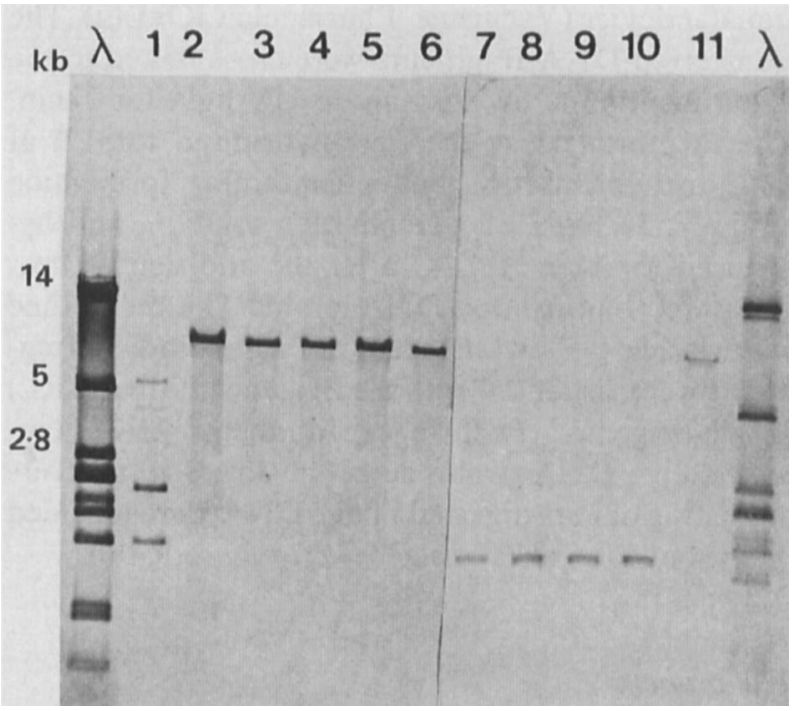

Fig. 1. AvaI restriction fragment patterns obtained with isolates from cases of invasive meningococcal disease associated with the Gloucester and Plymouth outbreaks. Tracks $\lambda$, PstI digest of $\lambda$ phage DNA; track 1, NG2b/2,9R (control); 2, B15/16R (Gloucester); 3, B15/16R (Gloucester); 4, B15/16R (Gloucester); 5, B15/16R (Gloucester); 6, B15/16R (Gloucester); 7, B15/16R (Plymouth); 8, B15/16R (Plymouth); 9, B15/16R (Plymouth); 10, B15/16R (Plymouth); 11, B15/16R (Pontefract).

patterns are represented in fig. 3 . The same 75 isolates were of 31 different serotypes and 39 isoenzyme electrophoretypes. None of the strains examined so far were refractory to digestion with the AvaI restriction enzyme; therefore, all strains have been typable by RFLP analysis, whereas some organisms are always non-typable or give incomplete typing results by serotyping.

The numerical index of discrimination (the probability of two unrelated strains being shown to be so) obtained with the different typing techniques used here were $0.91,0.92,0.90$ for serotyping, isoenzyme electrophoretotyping and RFLP typing respectively. Typing of four B15P1.16R isolates from the Plymouth area revealed one further RFLP type which was not included in the data used to calculate the index of discrimination. Within the 75 apparently unrelated strains were organisms whose phenotypic characterisation indicated that they were related to the epidemic strains currently found in the UK-B4P1.15 sulphonamide-resistant, non-groupable 4P1.15 sulphonamideresistant, and B15P1.16 sulphonamide-resistant (table I, nos. 1-12). This was confirmed by the correlation of a single RFLP type (type 1) and one isoenzyme electrophoretotype (ET type 1).

\section{Comparison of RFLP typing with MAb serotyping and isoenzyme electrophoretotyping}

Despite there being a greater number of ET types for the 75 isolates examined, several clusters of isolates with the same ET type gave rise to more than one RFLP type, e.g., isolates $41-45$ were all of ET type 23 whereas isolate 41 was RFLP type $15,42-44$ type 16 


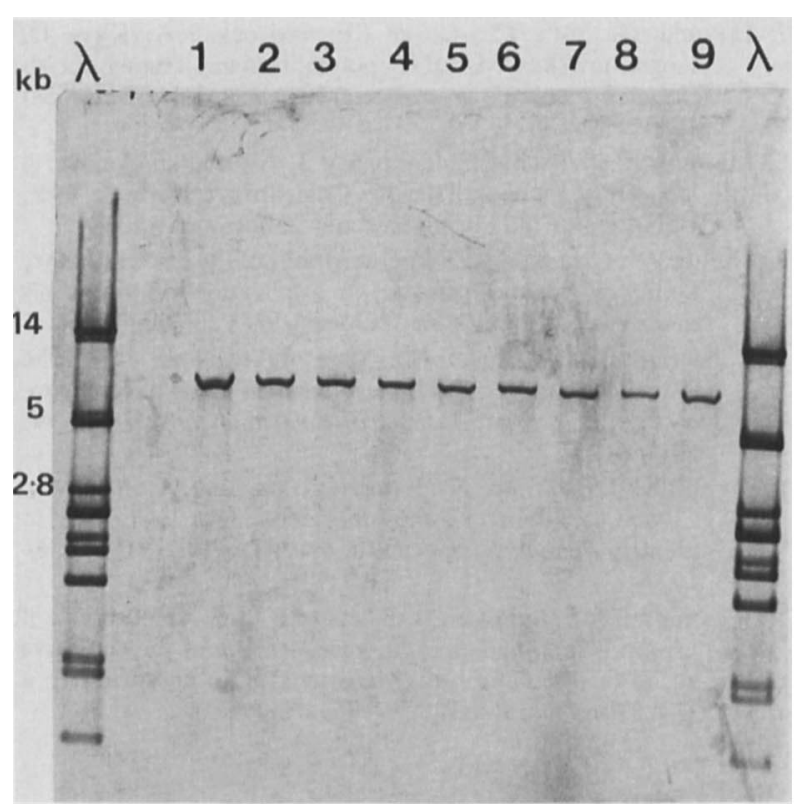

Fig. 2. AvaI restriction fragment patterns obtained with isolates from carriers sampled as part of the Stonehouse meningococcal survey. Tracks $\lambda$, PstI digest of $\lambda$ phage DNA; track 1, B15/16R;2, B15/16R; 3, B15/16R; 4, NG15/16R; 5, B15/16R; 6, NG15/16R; 7, B15/16R;8, B15/16R; 9, NG15/16R.

and 45 type 17 . The converse was also found in that isolates with divergent ET types such as isolates 33, 34 (both ET type 16) and isolates 73 and 74 (ET types 37 and 38 respectively) were all of the same RFLP pattern (type 11).

\section{Discussion}

The use of DNA probes to detect minor genomic variation between different isolates of pathogenic bacteria may avoid the pitfalls associated with variable expression of phenotypes. The RFLP method is based upon the detection of minor differences in base sequence which often cannot be discerned in the phenotype ${ }^{11}$ and relies to some extent on the assumption that differences in sequences in the small sample of DNA detected by the probe are correlated to the overall genetic difference between strains.

The cloned sequence employed as a probe in this study was selected from a random bacteriophage $\lambda$ genomic library prepared from the DNA of a B15P1.16 sulphonamide-resistant meningococcus. The probe size and choice of restriction enzyme gave rise to 1-8 bands from meningococcal strains. The probe sequence appears to be of broad specificity, being able to hybridise with all meningococcal isolates so far examined.

The results of this work demonstrate that restriction fragment patterns obtained for each isolate depend only on the source of the chromosomal DNA, the probe sequence employed and the specificity of the restriction endonuclease employed. The small number of bands produced by most isolates greatly facilitates

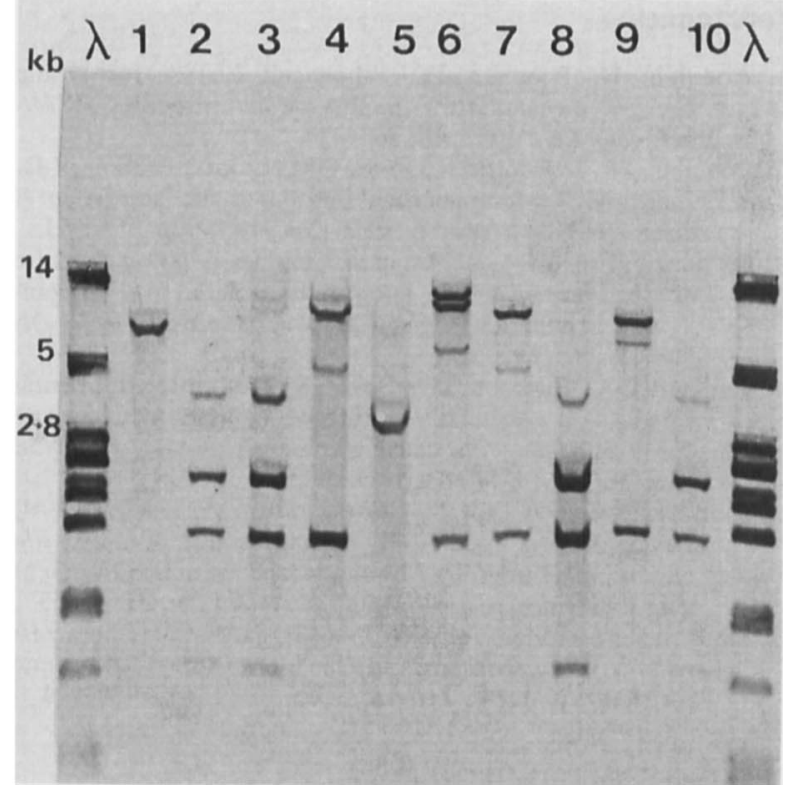

Fig. 3. Distinct $A v a$ I restriction fragment patterns obtained with 10 unrelated strains detected with probe $\lambda \mathrm{MN} 3$. Track 1, B4/15R (RFLP type 1); 2, B14/15S (2); 3, NG5(3); 4, NG5(6); 5, B15(7); 6, NGS(8); 7, NG4:P1/15S(6); 8, 2 NT/15S(3); 9, C2bs(9); 10, B2aS(2). Tracks 2, 10, 3, 8 and 4, 7 show identical patterns obtained with isolates with different phenotypes.

the interpretation and identification of the respective RFLP type of an isolate. This is in sharp contrast to the problems of interpreting the complex restriction fragment patterns visualised by staining total genomic digests which has also been used for differentiation of meningococci. ${ }^{12}$ The calculated index of discrimination confirms the excellent discriminatory ability of all three techniques. The presence of different phenotypes within a genetically homogeneous group of organisms (isolates 1-12) demonstrates the disadvantage of using only phenotypic typing for epidemiological surveillance of meningococci.

Differences found here between isoenzyme electrophoretotyping and RFLP typing may reflect the probability that different genomic regions are exploited by each of these techniques.

With regard to the results with B15P1.16 strains from Plymouth and Gloucestershire, the application of RFLP typing to these apparently phenotypically homogeneous organisms from two geographical locations demonstrates that there are two genetically distinct groups of organisms of the same ET type which were thought previously to be epidemiologically related. This suggests that the use of RFLPs may increase our understanding of meningococcal population genetics.

The technique described is readily applicable to epidemiological research because it uses a single probe and a non-radioactive methodology. The ease of interpretation of the restriction patterns obtained and the fact that RFLP analysis gives some indication of genetic relationships between strains make this a most useful additional tool for epidemiological typing of meningococci. 


\section{References}

1. Abdillahi H, Poolman JT. Whole-cell ELISA for typing Neisseria meningitidis with monoclonal antibodies. FEMS Microbiol Letts 1987; 48: 367-371.

2. Poolman JT, Jónsdóttir K, Jones DM, Lind I, Frøholm LD Zanen HC. Meningococcal serotypes and serogroup B disease in North-West Europe. Lancet 1986; 2: 555-558.

3. Olyhoek T, Crowe BA, Achtman M. Clonal population structure of Neisseria meningitidis serogroup A isolated from epidemics and pandemics between 1915 and 1983. Rev Infect Dis 1987; 9: 665-692.

4. Caugant DA, Frøholm LO, Bøvre $\mathrm{K}$ et al. Intercontinental spread of a genetically distinctive complex of clones of Neisseria meningitidis causing epidemic disease. Proc Natl Acad Sci USA 1986; 83: 4927-4931.

5. Saunders NA, Harrison TG, Haththotuwa A, Kachwalla N Taylor AG. A method for typing strains of Legionella pneumophila serogroup 1 by analysis of restriction fragment length polymorphisms. $J$ Med Microbiol 1990; 31: 45-55.

6. De Buyser M-L, Morvan A, Grimont F, El Solh N. Characterization of Staphylococcus species by ribosomal RNA gene restriction patterns. J Gen Microbiol 1989; 135: 989-999.
7. LiPuma JJ, Stull TL, Dasen SE, Pidcock KA, Kaye D, Korzeniowski OM. DNA polymorphisms among Escherichia coli isolated from bacteriuric women. J Infect Dis 1989; 159 : 526-532.

8. Maniatis T, Fritsch EF, Sambrook J. Molecular cloning: a laboratory manual, 1st edn. Cold Spring Harbour, NY, CSH Press, Cold Spring Harbour Laboratory. 1982.

9. Hunter PR, Gaston MA. Numerical index of the discriminatory ability of typing systems: an application of Simpson's index of diversity. J Clin Microbiol 1988; 26: 2465-2466.

10. Cartwright KAV, Stuart JM, Jones DM, Noah ND. The Stonehouse survey: nasopharyngeal carriage of meningococci and Neisseria lactamica. Epidemiol Infect 1987; 99: 591-601.

11. Tompkins LS, Troup N, Labigne-Roussel A, Cohen ML. Cloned, random chromosomal sequences as probes to identify Salmonella species. J Infect Dis 1986; 154: 156162.

12. Kristiansen B-E, Sørensen B, Bjorvatn B et al. An outbreak of Group B meningococcal disease: tracing of the causative strain of Neisseria meningitidis by DNA fingerprinting. $J$ Clin Microbiol 1986; 23: 764-767. 